409. 自動化総合健診における血中ペプシノーゲンの検討

\title{
A study of serum pepsinogens in AMHTS
}

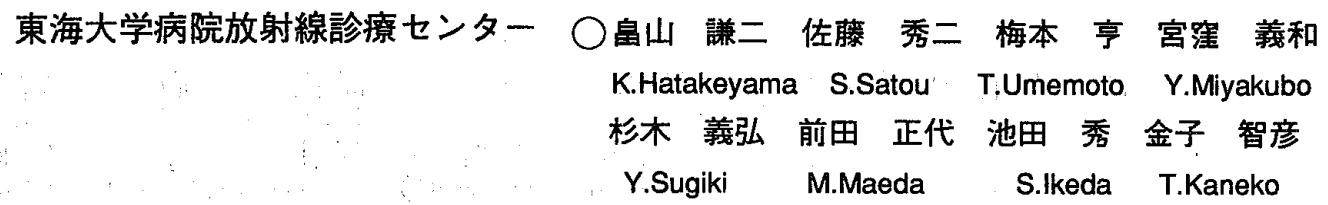

【目 的】早期胃癌の発見に有効と言われている血中ペプシノーゲン検査の血中PG1・PG 2 值を得ることが できた．このデータを参考に，直接胃X線検査（胃X線検查）と血中ペプシノーゲン検査（血中PG検査）の 比較検討を行った.

【方 法】、胃X線検査を実施した3219名の血中PG值を測定した.このうち胃X線検查の結果, 要精検と なった402名中当院にて内視鏡検查を行った173名を対象に，胃X線検查と血中PG検査の成績を，内視鏡㭘査 結果と病理診断結果を基に比較した．なお血中PG検査の陽性者とするCUT OFF值はPG1 $\leqq 70.0$ 及びPG1／ PG2 3.0とした.

【結 果】同じ対象群に対して，胃X線検査の要精検者は402名，血中PG検査では1093名あり，要精検率は 血中PG検查の方が胃 $X$ 線検查に比べ約 3 倍と高值となった（Fig. 1)．また血中PG検查は 50 歳代以上の陽 性率が特に高值となる (Fig. 2)，内視鏡検査・病理診断結果との比較は, 潰湯及び潰瘍疫痕・ポリープで は，胃X線検查の精度が高いが，胃炎については血中PG検查の方が高くなっている（Fig.3）．さらに胃炎の 中でも萎縮を伴った胃炎に限るとその的中率は約 $80 \%$ 近くにもなる．癌症例については，胃X線検査及び血 中PG検查での指摘は 1 名, 胃 X 線検査のみの指摘は 1 名, 血中PG検查のみの指摘は 1 名の合計 3 名であっ た(Table.1):

【考 察】血中PG検査は，PG1・PG2 值をそれぞれ微量の血清で測定することで慢性菱縮性胃焱をスクリー ニングするものなので大量処理が可能であり，胃X線検查に比べ苦痛が少ないなどの利点がある．しかし， 今後使用するにあたり次の問題点を検討しなければならないと思われる.

1. 胃 X線検查に比べ陽性率が高く，さらに50歳代以上になるとその傾向は強くなる．２．一度陽性とな ると次回以降も陽性となる確率が高い：3，胃の手術をした人は，PG值が低值となり陽性者となる. したがって現時点で血中PG検査は胃 X線検査に置きかわることのできる検查ではないと判断する.

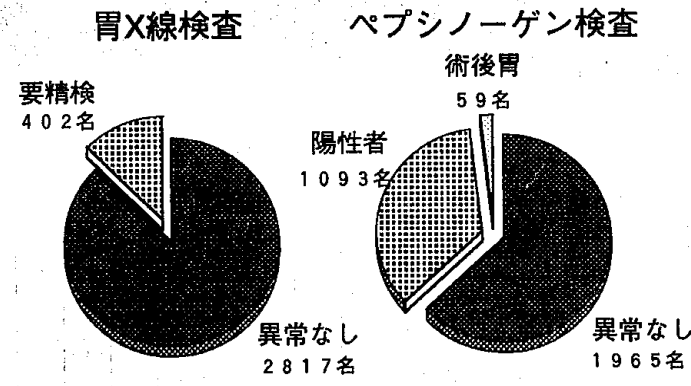

Fig.1 陽性者数の比較

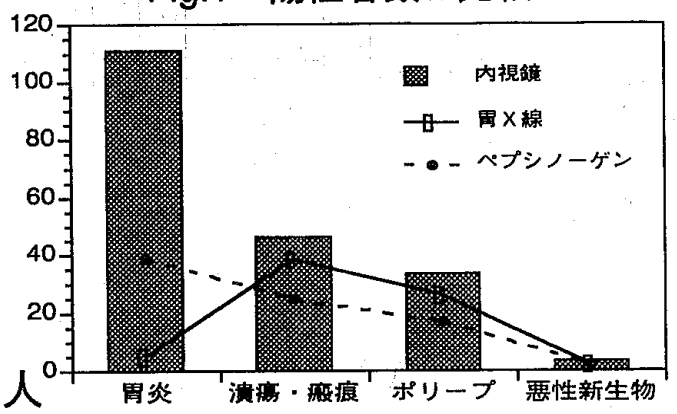

Fig.3 各検査の精度比較

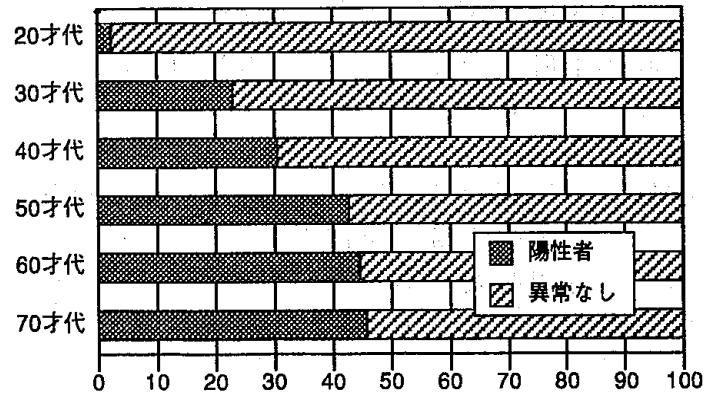

Fig.2 P G 検査の陽性率（年齢別）

\begin{tabular}{|c|c|c|c|c|c|c|}
\hline & 年龋 & $P G 1$ & $P G 2$ & $P G 1 / P G 2$ & $P G$ & 胃X缐 \\
\hline 症列 1 & 54 & 14.9 & 10.4 & 1.4 & 陽性 & 要垔查 \\
\hline 症例 2 & 62 & 97.2 & 43.8 & 2.2 & 異常なし & 要精査 \\
\hline 症例 3 & 72 & 12.1 & 9.0 & 1.3 & 踼性 & 異常なし \\
\hline
\end{tabular}

Table 1.胃癌症例 